\title{
Cost-Effectiveness Analysis of Pharmacotherapy for Hematemesis-Melena Treatment in Hospitalized Patients with Hepatic Cirrhosis
}

\author{
Doddy de Queljoe ${ }^{1}$, Amelia Lorensia $^{1, *}$, Liana Widharta ${ }^{1}$, Sugiarto Widjaja ${ }^{2}$ \\ ${ }^{1}$ Pharmacy Faculty, Surabaya University, J1. Ngagel Jaya Selatan 169, Surabaya, Indonesia \\ ${ }^{2}$ Adi Husada Undaan Wetan Hospital, J1. Undaan Wetan No.40-44, Surabaya, Jawa Timur, Indonesia \\ ${ }^{*}$ Corresponding author. E-mail: amelia.lorensia@gmail.com
}

\section{Abstract}

$\mathrm{B}$ ACKGROUND: Acute variceal haemorrhage is a complication of cirrhosis that can be life threatening. It is a pharmacist's duty to ensure therapeutic and pharmaceutical care which is not only safe and effective for the patient but also is cost-effective in order to attain improvement of the patient's quality of life. Therefore, pharmacoeconomic evaluation especially cost-effectiveness analysis (CEA), which compares costs and consequences of drug therapy, is needed. This study was aimed to evaluate the therapeutic cost-effectiveness of hematemesis-melena treatment in hepatic cirrhotic patients.

METHODS: A total of 42 patients receiving vitamin K and vitamin $\mathrm{K}$-transamin were studied retrospectively from patients' medical records in 2 years and analyzed with cost-effectiveness grid and average cost-effectiveness ratio (ACER) based on Child-Turcotte-Pugh (CTP) Score.

RESULTS: Cost-effectiveness grid was dominant for vitamin $\mathrm{K}$ in patients with CTP Score A. ACER analysis showed a lower score for vitamin $\mathrm{K}$ in all patients included CTP Score classification. There was no significant difference in duration of cessation of bleeding treatment in patients with vitamin $\mathrm{K}$ compared with vitamin $\mathrm{K}$-transamin in patients with CTP Score A and B, while significant difference was found in patients with CTP Score C.

CONCLUSION: Vitamin K appeared to be more costeffective as compared with vitamin K-transamin in all patients. The use of vitamin $\mathrm{K}$ had greater benefit than the combination with transamin in all patients and CTP Score classification, and thus should be considered as a primary therapy. Therefore, transamin addition as an alternative therapy for hepatic cirrhosis patients with hematemesis-

\section{Abstrak}

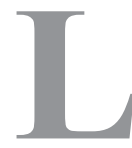

ATAR BELAKANG: Pendarahan varises akut merupakan komplikasi sirosis yang dapat mengacam jiwa. Hal ini merupakan tugas farmasis untuk memastikan terapi dan pelayanan kefarmasian yang tidak hanya aman bagi pasien tetapi juga mempunyai biaya yang efektif yang bertujuan untuk memperbaiki kualitas hidup pasien. Oleh karena itu, diperlukan evaluasi farmakoekonomi terutama cost-effectiveness analysis (CEA) yang membandingkan biaya dan konsekuensi dari terapi hematemesis-melena pada pasien sirosis hepatik.

METODE: Total dari 42 pasien yang menerima vitamin $\mathrm{K}$ dan vitamin K-transamin diteliti secara retrospektif dari rekam medik selama 2 tahun, dan dianalisis dengan costeffectiveness grid dan average cost-effectiveness ratio (ACER) berdasarkan Child-Turcotte-Pugh (CTP) Score.

HASIL: Cost-effectiveness grid menunjukkan bahwa dominant untuk vitamin K pada pasien dengan CTP Score A. Analisis ACER menunjukkan nilai yang lebih rendah pada vitamin K pada semua pasien meliputi klasifikasi CTP Score. Tidak ada perbedaan bermakna untuk durasi dari penghentian terapi pendarahan pada pasien dengan vitamin $\mathrm{K}$ dibandingkan dengan vitamin $\mathrm{K}$-transamin pada pasien dengan CTP Score A dan B, sedangkan perbedaan signifikan ditemukan pada pasien dengan CTP Score C.

KESIMPULAN: Vitamin $\mathrm{K}$ terbukti lebih efektif biaya dibandingkan dengan vitamin K-transamin pada semua pasien. Penggunaan vitamin K memiliki keuntungan yang lebih besar dibandingkan dengan kombinasi dari transamin pada semua pasien dan klasifikasi CTP Score, sehingga seharusnya dipertimbangkan sebagai terapi primer. Oleh karena itu penambahan transamin sebagai terapi alternatif 
melena should be considered.

KEYWORDS: CEA, cost-effectiveness analysis, ChildTurcotte-Pugh Score, hepatic cirrhosis, hematemesismelena, vitamin $\mathrm{K}$, transamin

Indones Biomed J. 2013; 5(1): 43-50 pada pasien sirosis hepatik harus dipertimbangkan.

KATA KUNCI: CEA, cost-effectiveness analysis, ChildTurcotte-Pugh Score, sirosis hepatik, hematemesis-melena, vitamin $\mathrm{K}$, transamin

\section{Introduction}

The liver is a major site of metabolism of various drugs. In patients with liver disease the liver capacity for metabolism/ elimination of drugs may be disturbed.(1) Cirrhosis of the liver (hepatic cirrhosis) is one of the severe liver diseases that is chronic, irreversible, and causes high mortality(2), and this occupies the twelfth leading cause of death in the United States(3).

Hepatic cirrhosis is a diffuse process characterized by fibrosis and changes of the normal liver structure to abnormal nodule structure.(4) As a result, scar tissue is formed due to injury or long-term liver disease, and it causes the liver to fail its normal functions such as protein synthesis, cleaning process of the blood, resistance to infection, digesting foods, and energy storage.(5) The degree of severity of the liver disease can be divided into three categories with ChildTurcotte-Pugh (CTP) Score. CTP Classification is a system used to classify the degree of liver damage or development of liver disease in hepatic cirrhosis patients. $(6,7)$

There are some complications of cirrhosis such as ascites, hepatic encephalopathy (HE), hepatorenal syndrome, SBP (spontaneous bacterial peritonitis), and esophageal varices.(3) Fifty percent of patients with alcoholic cirrhosis will develop esophageal varices after 2 years after being diagnosed, and $70-80 \%$ patients in 10 years. About $25-35 \%$ patients with cirrhosis and large esophageal varices will experience variceal haemorrhage. Acute variceal haemorrhage is a complication of cirrhosis which has life threatening impact(2), and acts as a major cause of death in cirrhosis patients(8). The increase in portal pressure due to increased resistance to blood flow to the liver is largely due to the distortion of the liver structure to fibrous tissue and regenerative nodules and intra hepatic active vasoconstriction by $20 \%-30 \%$ of the increased intra hepatic resistance, and a decrease in endogenous production of nitric oxide.(9)

One of the functions of the liver is to produce several clotting factors (including prothrombin and fibrinogen) as well as to produce bile salts that are necessary for gastrointestinal absorption of vitamin $\mathrm{K}$, which is needed to produce coagulation factor.(10) Deficiency in vitamin K can cause blood clotting disorders, to cause the patients to be prone to bleeding. On the other hand, transamin (tranexamic acid (TXA)), which is an antifibrinolytic agent, has proven useful for controlling bleeding in some conditions, especially is more favorable in small superficial lesions such as gastric erosion and in esophageal varices(11), and proven to provide cost-effectiveness in cirrhosis(12).

Neff et al. had examined the economic impact of

Table 1. CTP Score.(6)

\begin{tabular}{lccc}
\multicolumn{1}{c}{ Parameter } & \multicolumn{3}{c}{ Numerical Score } \\
\cline { 2 - 4 } & $\mathbf{1}$ & $\mathbf{2}$ & $\mathbf{3}$ \\
\hline Ascites & None & Slight & Moderate / Severe \\
Encephalopathy & None & Slight / Moderate & Moderate / Severe \\
Bilirubin (mg/dL) & $<2.0$ & $2-3$ & $>3.0$ \\
Albumin (mg/L) & $>3.5$ & $2.8-3.5$ & $<2.8$ \\
Prothrombin time (seconds, increased) & $1-3$ & $4-6$ & $>6.0$ \\
\hline
\end{tabular}

Total Numerical Score CTP Class

$\begin{array}{cc}5-6 & \text { A } \\ 7-9 & \text { B } \\ 10-15 & \text { C }\end{array}$


various regimens used for prophylaxis and treatment of cirrhosis-related complications, and found it necessary to evaluate the costs and complications of cirrhosis-related complications.(13)

Cost-effectiveness analysis (CEA) used in accordance to the study objectives in assessing relationship between cost and outcome, which in this case is clinical outcome, and CEA is an important instrument in setting priorities for strategic planning of therapy. By measuring and comparing cost and consequences of an intervention, efficient relationship could be assessed and the resources needed in the future could be estimated.(14)

\section{Methods}

This study was a non-experimental research and used the retrospective approach. Data were obtained from adult patients' medical records which had major diagnosed hepatic cirrhosis cases.

In this study, the method used was CEA. Therapeutic cost and consequences of therapy were measured and compared.

\section{Research variables}

Dependent variables in this study were cost (cost of vitamin $\mathrm{K}$ and combination of vitamin K-transamin) and clinical outcome (duration of cessation of bleeding). Independent variables in this study were type of treatment and CTP score.

\section{Population and sample}

Population in this study was all the hospitalized hepatic cirrhosis patients with hematemesis-melena at Adi Husada Undaan Wetan Hospital, from January 2010 to December 2011. Patients were grouped based on their degree of liver disease with CTP score.

The number of samples was calculated based on formula(15):

$$
\mathrm{N}=\text { p.q. }\left(\mathrm{Z}_{1 / 2 \alpha} / \mathrm{b}\right)^{2}
$$

$\mathrm{N}=$ minimum sample number

$\mathrm{p} \quad=$ percentage proportion in first population group

$\mathrm{q}=$ percentage proportion in second population group $=1-p$

$\mathrm{Z}_{1 / 2 \alpha} \quad=$ degree of confidence coefficient in certain level of confidence (example 95 or $99 \%$ )

$\mathrm{b}=$ = estimate percentage error possibility on number of sample determination (about 0.1 or 0.5 )
Calculation of sample's number in this study:

$\mathrm{N}=$ p.q. $\left(\mathrm{Z}_{1 / 2 \alpha} / \mathrm{b}\right)^{2}=0.5 \times 0.5 \times(1.96 / 0.2)^{2}=24$ patients

Thus, the number of samples needed in each intervention group was 6 patients.

\section{Inclusion and Exclusion Criteria}

Inclusion criteria in this study were hepatic cirrhosis patients with hematemesis-melena, adult age $\geq 16$ years (16), and patients treated with vitamin $\mathrm{K}$ or combination of vitamin K-transamin. Exclusion criteria were patients who went home before the bleeding stopped, had not improved their clinical outcome, or died; patients who had not recovered from bleeding; patients with another kind of disease like hepatoma, or used another medication (for example oral vitamin $\mathrm{K}$ or oral transamin), which could interfere the treatment studied and outcome relationship; incomplete patient's medical record including diagnoses or clinical outcomes.

\section{Data Analysis Techniques}

Data obtained were analyzed with statistical method. First the normality of data was examined, then parametric (Anova one way, independent t-Test, and pooled t-Test) or non-parametric tests (Kruskal Wallis and Mann Whitney $\mathrm{U}$ test) were used to know the difference in duration of treatment until the bleeding stopped and the costs. Degree of significance used for the tests was 0.05 and the statistical program used was SPSS 17.0. Besides, conclusions were also made using cost-effectiveness grid and average costeffectiveness ratio (ACER) calculation.

\section{Calculation of ACER}

ACER was calculated based on the following formula(5) : ACER $=$ cost $/$ effectiveness.

\section{Results}

Effectiveness was calculated based on the percentage of cumulative duration of treatment until improvement was less than or equal to 1 day in all patients and in patients with CTP Score A and B, as well as the duration of treatment to improve less than or equal to 3 days in patients with CTP Score C. CTP Based on the effectiveness of therapy, in patients with CTP Score A found that vitamin $\mathrm{K}$ was more effective than vitamin K-effectiveness transamin although the difference was rather slight, in all patients and patients with CTP Score B and C, the effectiveness of vitamin $\mathrm{K}$-transamin was greater than vitamin $\mathrm{K}$. While the cost of treatment was only calculated based on the average cost of the therapeutic use of vitamin $\mathrm{K}$ and vitamin $\mathrm{K}$-transamin 
based on the length of treatment to get better. The higher the severity of liver cirrhosis, the longer the treatment will take and therefore contributes to the increasing number of drugs used to stop bleeding and will ultimately affect the cost of the used drugs. Based on calculation with ACER, it showed that vitamin $\mathrm{K}$ was more cost-effective than vitamin $\mathrm{K}$-transamin in all patients as well as patients with CTP Score A, B, and C.

At the test time difference of improving the treatment of the samples using parametric and nonparametric methods

Table 1. Cost-Effectiveness Grid for CEA.

\begin{tabular}{lcccc} 
& & \multicolumn{3}{c}{ Cost of Alternative A Relative to Alternative B } \\
\cline { 3 - 5 } & & Lower & Equal & Higher \\
\hline & Higher & + (dominant) & + & $+/$ - (trade off) \\
Effectiveness of Alternative A & Equal & + & Arbitrary & - \\
Relative to Alternative B & Lower & $+/$ - (trade-off) & - & - (dominated) \\
\hline
\end{tabular}

Table 3. Patients Cahracteristics

\begin{tabular}{|c|c|c|c|c|c|}
\hline & Whole Group $(\mathrm{n}=42)$ & CTP Score A $(n=13)$ & CTP Score B $(n=15)$ & CTP Score C $(n=14)$ & $p$ value \\
\hline Gender, male & $29(69.05 \%)$ & $7(53.85 \%)$ & $14(93.33 \%)$ & $8(57.14 \%)$ & 0.227 \\
\hline Gender, female & $13(30.95 \%)$ & $6(46.15 \%)$ & $1(6.67 \%)$ & $6(42.86 \%)$ & 0.146 \\
\hline Age, years & $59.12 \pm 13.41$ & $59.08 \pm 9.40$ & $54.80 \pm 15.46$ & $63.79 \pm 13.53$ & 0.057 \\
\hline Arterial systolic pressure, $\mathrm{mmHg}$ & $121.62(101.67-162.67)$ & $111.63(101.67-162.67)$ & $122(102.50-135.80)$ & $122.96(102.56-157)$ & 0.612 \\
\hline Arterial diastolic pressure, $\mathrm{mmHg}$ & $67.67(54-89)$ & $69.60(58.67-89)$ & $69.67(60.43-77.33)$ & $63.40(54-84.80)$ & 0.541 \\
\hline \multicolumn{6}{|l|}{ Therapy } \\
\hline Vitamin K & $18(42.86 \%)$ & $7(53.85 \%)$ & $5(33.33 \%)$ & $6(42.86 \%)$ & 0.846 \\
\hline Vitamin K-Transamin & $24(57.14 \%)$ & $6(46.15 \%)$ & $10(66.67 \%)$ & $8(57.14 \%)$ & 0.607 \\
\hline \multicolumn{6}{|l|}{ Cost } \\
\hline \multirow[t]{4}{*}{ Vitamin K (IDR) } & $12,641(8,471)$ & $5,550(0)$ & $11,100(3,924)$ & $22,200(7,020)$ & 0.000 \\
\hline & & $5,550(0)$ & $11,100(3,924)$ & $22,200(7,020)$ & 0.054 \\
\hline & & $5,550(0)$ & $11,100(3,924)$ & $22,200(7,020)$ & 0.000 \\
\hline & & & & & 0.001 \\
\hline \multirow[t]{4}{*}{ Vitamin K-Transamin (IDR) } & $62,643(31,773)$ & $44,975(15,737)$ & $53,970(26,954)$ & $86,737(34,170)$ & 0.033 \\
\hline & & $44,975(15,737)$ & $53,970(26,954)$ & $86,737(34,170)$ & 0.519 \\
\hline & & $44,975(15,737)$ & $53,970(26,954)$ & $86,737(34,170)$ & 0.025 \\
\hline & & & & & 0.042 \\
\hline \multirow[t]{4}{*}{ Hospitalization duration } & $6(3-14)$ & $6(3-14)$ & $5(3-14)$ & $8.5(3-14)$ & 0.000 \\
\hline & & $6(3-14)$ & $5(3-14)$ & $8.5(3-14)$ & 0.230 \\
\hline & & $6(3-14)$ & $5(3-14)$ & $8.5(3-14)$ & 0.000 \\
\hline & & & & & 0.000 \\
\hline \multirow[t]{4}{*}{ Duration of treatment to bleed stopped } & $1.5(1-6)$ & $1(1-5)$ & $1(1-6)$ & $2.5(1-5)$ & 0.000 \\
\hline & & $1(1-5)$ & $1(1-6)$ & $2.5(1-5)$ & 0.023 \\
\hline & & $1(1-5)$ & $1(1-6)$ & $2.5(1-5)$ & 0.000 \\
\hline & & & & & 0.003 \\
\hline \multirow[t]{4}{*}{ Duration of treatment } & $4(1-14)$ & $3(1-7)$ & $3(2-9)$ & $7(2-14)$ & 0.002 \\
\hline & & $3(1-7)$ & $3(2-9)$ & $7(2-14)$ & 0.673 \\
\hline & & $3(1-7)$ & $3(2-9)$ & $7(2-14)$ & 0.001 \\
\hline & & & & & 0.005 \\
\hline
\end{tabular}

Data presented as mean \pm standard deviation. Significant difference if $p \leq 0.05$. 
Table 4. Patients Cahracteristics in CTP Score A, B and C

\begin{tabular}{|c|c|c|c|}
\hline \multicolumn{4}{|c|}{ Patient Characteristics in CTP Score A } \\
\hline & Vitamin K $(n=7)$ & Vitamin K-Transamin $(n=6)$ & p value \\
\hline Gender, male & $3(42.86 \%)$ & $4(66.67 \%)$ & 0,705 \\
\hline Gender, female & $4(57.14 \%)$ & $2(3.33 \%)$ & 0,414 \\
\hline Age, years & $64 \pm 10.50$ & $53.33 \pm 2.50$ & 0,034 \\
\hline Arterial systolic pressure, $\mathrm{mmHg}$ & $130.33(101.67-140.56)$ & $114.9(101.86-162.67)$ & 0.860 \\
\hline Arterial diastolic pressure, $\mathrm{mmHg}$ & $62.67(58.67-75.22)$ & $74.17(61.71-91.12)$ & 0,027 \\
\hline Hospitalized duration & $4(3-9)$ & $4(3-8)$ & 1.000 \\
\hline Duration of treatment to bleed stopped & $1(1-1)$ & $1(1-2)$ & 0.280 \\
\hline Duration of treatment & $3(1-7)$ & $3.5(2-6)$ & 0,941 \\
\hline Cost & $5,550(0)$ & $44,975(15,737)$ & 0,001 \\
\hline \multicolumn{4}{|c|}{ Patient Characteristics in CTP Score B } \\
\hline & Vitamin $K(n=5)$ & Vitamin K-Transamin $(n=10)$ & p value \\
\hline Gender, male & $4(80 \%)$ & $10(100 \%)$ & 0,109 \\
\hline Gender, female & $1(20 \%)$ & $0(0 \%)$ & - \\
\hline Age, years & $52 \pm 21.06$ & $57.2 \pm 12.97$ & 0,323 \\
\hline Arterial systolic pressure, $\mathrm{mmHg}$ & $109.87(102.5-149.3)$ & $129.59(108.33-157)$ & 0.170 \\
\hline Arterial diastolic pressure, $\mathrm{mmHg}$ & $65.6(62.37-69.6)$ & $74.46(60-84.8)$ & 0,061 \\
\hline Hospitalization duration & $6(5-10)$ & $5(3-8)$ & 0,107 \\
\hline Duration of treatment to bleed stopped & $2(1-3)$ & $1(1-3)$ & 0,103 \\
\hline Duration of treatment & $6(5-9)$ & $2.5(2-6)$ & 0,007 \\
\hline Cost & $11,100(3,924)$ & $53,970(26,954)$ & 0,001 \\
\hline \multicolumn{4}{|c|}{ Patient Characteristics in CTP Score C } \\
\hline & Vitamin $K(n=6)$ & Vitamin K-Transamin $(\mathrm{n}=8)$ & p value \\
\hline Gender, male & $3(50 \%)$ & $5(62.5 \%)$ & 0.480 \\
\hline Gender, female & $3(50 \%)$ & $3(37.5 \%)$ & 1.000 \\
\hline Age, years & $62.67 \pm 19.45$ & $64.62 \pm 8.23$ & 0,801 \\
\hline Arterial systolic pressure, $\mathrm{mmHg}$ & $109.88(102.56-132.5)$ & $129.31(110.14-139.71)$ & 0,022 \\
\hline Arterial diastolic pressure, $\mathrm{mmHg}$ & $61.47(54.93-78.36)$ & $72.1(60.17-80.43)$ & 0,117 \\
\hline Hospitalized duration & $11(8-14)$ & $8.5(4-13)$ & 0,134 \\
\hline Duration of treatment to bleed stopped & $4.5(2-5)$ & $2.5(1-3)$ & 0.010 \\
\hline Duration of treatment & $10(7-14)$ & $5.5(2-9)$ & 0,007 \\
\hline Cost & $22,200(7,020)$ & $86,737(34,170)$ & 0,002 \\
\hline
\end{tabular}

of analysis showed a significant difference $(\alpha=0.05)$ in comparison to the longer treatment improved in patients with CTP Score A, B and C (Table 4). Comparison of the lengths of time of treatment to improve in patients with vitamin K therapy in patients with CTP Score A and B were not significant, while comparison of the CTP Score A and C with $\mathrm{B}$ and $\mathrm{C}$ showed significant differences. The duration lengths of treatment to improve therapy in patients with vitamin K-transamin in patients with CTP Score A and B were not significant, while in comparison the CTP Score $\mathrm{A}$ and $\mathrm{C}$ with $\mathrm{B}$ and $\mathrm{C}$ it showed significant differences $(\alpha=0.05)$. The result of the CTP Score, duration of treatment to improve the comparison between patients using vitamin $\mathrm{K}$ and vitamin $\mathrm{K}$-transamin was not significant at the CTP Score A and B, while the CTP Score C results were significant $(\alpha=0.05)$. Based on the cost of the use of vitamin $\mathrm{K}$ only and vitamin K-transamin in the study samples, the result was a significant difference in comparison with the cost of treatment using vitamin $\mathrm{K}$ and vitamin $\mathrm{K}$-transamin liver cirrhosis in patients with CTP Score A, B, and C (Table $6)$. 
Table 5. ACER in all patients.

\begin{tabular}{lcc}
\hline & Vitamin K & Vitamin K-transamin \\
\hline Total Cost to treat all patients & IDR 12,641 & IDR 62,643 \\
Effectiveness & $44.44 \%$ cure rate & $58.33 \%$ cure rate \\
ACER & $\frac{\text { IDR } 12,641}{0.44}=$ IDR 28,731 & $\underline{\text { IDR 62,643 }}=$ IDR 108,006 \\
\hline
\end{tabular}

Table 6. ACER in patients with CTP Score A, B and C.

\begin{tabular}{|c|c|c|c|}
\hline CTP Score & & Vitamin K & Vitamin K-transamin \\
\hline \multirow{3}{*}{$\mathbf{A}$} & Total Cost to treat all patients & IDR 5,550 & IDR 44,975 \\
\hline & Effectiveness & $100 \%$ cure rate & $83.33 \%$ cure rate \\
\hline & ACER & $\frac{\mathrm{IDR} 5,550}{1}=\operatorname{IDR} 5,550$ & $\frac{\text { IDR } 44,975}{0.83}=$ IDR 54,186 \\
\hline \multirow{3}{*}{ B } & Total Cost to treat all patients & IDR 11,100 & IDR 53,970 \\
\hline & Effectiveness & $20 \%$ cure rate & $70 \%$ cure rate \\
\hline & ACER & $\frac{\operatorname{IDR} 11,100}{0.20}=\operatorname{IDR} 55,500$ & $\frac{\operatorname{IDR} 53,970}{0.70}=\operatorname{IDR} 77,100$ \\
\hline \multirow{3}{*}{$\mathbf{C}$} & Total Cost to treat all patients & IDR 22,200 & IDR 86,737 \\
\hline & Effectiveness & $33.33 \%$ cure rate & $100 \%$ cure rate \\
\hline & ACER & $\frac{\operatorname{IDR} 22,200}{0.33}=\operatorname{IDR} 67,272$ & $\frac{\text { IDR } 86,737}{1}=\operatorname{IDR} 86,737$ \\
\hline
\end{tabular}

\section{Discussion}

One of the important pharmacist's responsibilities in clinical pharmacy is to ensure good therapeutic outcome and pharmaceutical care which must not only be safe and effective, but also have a high value from economic and humanistic aspects. In fact, pharmacy profession would not succeed in their role to provide pharmaceutical care without pharmaco-economic knowledge.(17) Therefore, pharmacoeconomic evaluation like CEA which compares cost and effectiveness of therapy is needed.(18,19) The cost of transamin is higher than the cost of vitamin $\mathrm{K}$, and to know whether addition of transamin in vitamin $\mathrm{K}$ monotherapy is needed in clinical practice, cost-effectiveness evaluation is required.

In this research, the cause of the incident of hematemesis-melena was not confirmed. PVT is caused by increased hepatic resistance in cirrhosis, resulting in deterioration in the portal venous outflow, vascular micro thrombosis secondary to vascular ischemia and infarction may lead to the heart, with the loss of liver tissue (parenchymal extinction) being replaced by fibrotic tissue. (20) The incident is most commonly caused by portal PVT that can contribute to significant morbidity and mortality. Cirrhotic patients with PVT should be screened for varices and then anti coagulated with low-molecular-weight heparin for at least a 6-month period. Newer evidence suggests that prophylactic anticoagulation in patients with cirrhosis may have a role in clinical management with decreased incidence of PVT and improved survival.(21)

The patients characteristics can be seen in Table 3, while patients characteristics based on CTP classification can be seen in Table 4. $p$ value indicates significant difference if $p \leq 0.05$. In this study, there was one group with a number of samples less than 6 , and it was CTP score B group using vitamin $\mathrm{K}$ with just 5 subjects. This was due to the limitation of hepatic cirrhosis patients with hematemesis-melena. 
The difference of liver severity will take effect on therapeutic effectiveness. The higher the liver damage, the lower the therapeutic effectiveness, due to decrease of liver function for coagulation factor synthesis $(1,22)$, and if there is any hepatocellular disease or if the liver cell couldn't synthesize blood coagulation factor, vitamin $\mathrm{K}$ given to patients wouldn't be effective(23).

Beside CTP Score, there is another instrument used to classify the severity of the liver damage, which is a newer method called model of end stage liver disease (MELD). There are some benefits of MELD, like no subjective assessment like CTP score (ascites, hepatic encephalopathy), but hepatologists generally do not use MELD because not all laboratories use internationalized ratio (INR) which is one of MELD components as coagulation marker in hepatic cirrhosis patient, and there is no clear value limitation on MELD. Besides that, MELD scoring needs calculation, therefore quick and simple measurement couldn't be applied.(24)

In Indonesia, the biggest risk factor as the cause of hepatic cirrhosis progression of hepatitis $\mathrm{C}$ and $\mathrm{B}$ infections followed by hemochromatosis(25) rather than alcohol, because of the difference between the amount of alcohol consumed by people in western countries than people in Indonesia. The development of hepatitis $\mathrm{C}$ to hepatic cirrhosis usually take years or decades, with average of 20 years.(26) Most of hepatic cirrhosis patients are elderly people, usually in the range of 52-69 years old due to hepatic cirrhosis development which takes years or decades. From this study it is known that hepatic cirrhosis symptoms appears averagely at the age of 51 years and culminates at the range of 52-69 years.

In this study bleeding mostly stopped at the first day after medication, although the patient had bled for days before hospitalized. This is in accordance with literature that claims when vitamin $\mathrm{K}$ is given parenterally, prothrombin time (PT) may need 12 to 24 hours to normal, although improvement may happen in 1 to 2 hours(27), whereas transamin has $t^{1 / 2}=2$ hours(28). Therefore, it is most likely that patient's bleeding could be stopped at the first day of treatment.

Anti-fibrinolytic therapy has been shown to be useful in controlling bleeding in some conditions, especially in patients with gastric erosion and also in esophageal varices. Anti-fibrinolytic effect is not associated with improved systemic fibrinolysis, but more due to the inhibition of local fibrinolysis in gastroduodenal mucosa.(10) Therefore, the use of transamin in addition to the use of vitamin $\mathrm{K}$ can be an option, but there is no sufficient evidence supporting a recommendation on the use of transamin in the treatment of gastrointestinal bleeding and bleeding from varices.(7) Regardless of the fact there is an evidence that transamin is a useful treatment for refractory bleeding due to gastric antral vascular ectasia in patients with cirrhosis.(29)

Comparative effectiveness based on pharmacoeconomics reviews, performed by calculating the percentage of patients with cirrhosis of the liver with hematemesis melena $\leq 1$ day in all patients and in patients with CTP Score A and B, as well as old treatment until the bleeding that stopped $\leq 3$ days in patients with CTP Score C.

Data were analyzed using cost-effectiveness grid and ACER. From the cost-effectiveness in the table grid (Table 2) it can be seen that vitamin $K$ has a dominant outcome in patients with CTP Score A and trade off on all patients as well as patients with CTP Score B and C. Consider further follow up on the results of the trade off is using ACER. From the dominant finding in the results, it can be seen that treatment with vitamin $\mathrm{K}$ have a lower cost with higher effectiveness than vitamin K-transamin, so it can be concluded that vitamin $\mathrm{K}$ is more cost-effective than vitamin K-transamin.

Based on the calculation of ACER (Table 5 and 6), it showed the value of vitamin $\mathrm{K}$ was smaller than the vitamin $\mathrm{K}$-transamin, so it can be concluded that vitamin $\mathrm{K}$ is more cost-effective than vitamin $\mathrm{K}$-transamin in all patients as well as in patients with CTP Score A, B, and C.

There are some limitations of this study including that of the number of samples which was too small, because it was taken from 1 hospital even in 2 years, and that's why the data were not homogenous and the distribution was not normal either. We recommend that in the future studies using more samples with a longer time span should be carried out so the samples can be homogeneous and have normal distribution. The next limitation was the observed cost, in which this study only examined the cost of drugs, while other costs such as hospital and physician costs, laboratory costs, etc., were not observed. Another limitation was that the outcome of treatment was observed only until the bleeding stopped (the duration), other outcomes associated with bleeding such as PT was not observed. PT is a laboratory test needed to evaluate blood coagulation rate. Decrease of PT is an expected result from bleeding medication.

\section{Conclusion}

The use of vitamin $\mathrm{K}$ therapy is more cost-effective than combination therapy of vitamin K-transamin in all patients with liver cirrhosis and hematemesis-melena, and in 
patients with CTP score A, B, and C. This conclusion should be regarded with caution due to its limitation and further research is needed.

Suggestion is given for further research using a prospective design so that the results obtained can be representative of the actual condition of the patient and confounding variables can be better controlled so as to obtain a good study of the relationship between risk factors and effects. In addition, the number of samples should be enlarged in order to get more homogeneous data and normal distribution, other components of cost such as cost of hospital, doctor, etc. could be calculated, not only the cost of therapy vitamin $\mathrm{K}$ or vitamin $\mathrm{K}$-transamin, and the outcome observed is not only of the duration of bleeding, but also Prothrombin Time, side effects, and other factors that affect bleeding in patients.

\section{Acknowledgement}

This research was supported by the Research and Community Service Institution of the University of Surabaya (Lembaga Penelitan dan Pengabdian Kepada Masyarakat Ubaya), Surabaya.

\section{References}

1. Kenward R, Tan CK. Penggunaan Obat pada Gangguan Hati. In: Aslam M, Tan CK, Prayitno A, editors. Farmasi Klinis-Menuju Pengobatan Rasional dan Penghargaan Pilihan Pasien. Surabaya: Elex Media Komputindo; 2003. p. 155-6.

2. Sease JM, Timm EG, Stragand JJ. Portal Hypertension and Cirrhosis. In: Dipiro JT, Talbert RL, Yee GC, editors. Pharmacotherapy A Pathophysiologic Approach, 7th ed. Berkshire: McGraw Hill Medical; 2008. p. 633-47.

3. Runyon BA. Management of Adult Patients with Ascites Due to Cirrhosis: An Update. American Association for the Study of Liver Diseases. All American Association for the Study of Liver Diseases. 2009; 49: 2087.

4. Crawford, James M. The Liver, Gall Bladder, and Billiary Tract. In Kumar V, Abbas AK, Fausto N, Mitchell R, editors. Robbins Basic Pathology. 8th ed. Philadelphia: Saunders Elsevier; 2007. p. 631-51.

5. National Institute of Health. Cirrhosis in Medline Plus (online). 2012.

6. Martin P, Friedman LS. Assessment of liver function and diagnostic studies, In: Friedman LS, Keeffe EB, editors Handbook of Liver Disease. 2nd ed. Philadelphia: Churchill Livingstone; 2004. p. 1-15.

7. Scottish Intercollegiate Guidelines Network (SIGN).Management of acute upper and lower gastrointestinal bleeding-A National Clinical Guideline. 2008.

8. Sadovsky R. Management of Patients with Incidental Esophageal Varices. Am Fam Physician. 2005; 7: 980-5.

9. Tsao GG, Sanyal AJ, Grace ND, Carey W, and the Practice Guidelines Committee of the American Association for the Study of Liver Diseases, the Practice Parameters Committee of the American College of Gastroenterology. Prevention and Management of Gastroesophageal Varices and Variceal Hemorrhage in Cirrhosis.
American Association for the Study of Liver Diseases Practice Guideline. 2007; 46: 924-5.

10. Vander AJ, Sherman J, Luciano DS. The Digestion and Absorption of Food, In: Vander AJ, Sherman J, Luciano DS, editors. Human Physiology: The Mecanism of Body Function 8th ed. Philadelphia: The McGraw-Hill Companies; 2001.

11. Biggs JC, Hugh TB, Dodds AJ. Tranexamic acid and upper gastrointestinal haemorrhage-a double-blind trial. Gut. 1976; 17:729-34.

12. Guerriero C, Cairns J, Perel P, Shakur H, Roberts I. Cost-Effectiveness Analysis of Administering Tranexamic Acid to Bleeding Trauma Patients Using Evidence from the CRASH-2 Trial. PLoS ONE. 2011; 6: e18987.

13. Neff GW, Kemmer N, Duncan C, Alsina A. Update on the management of cirrhosis-focus on cost-effective preventative strategies. Clinicoecon Outcomes Res. 2013; 12: 143-52.

14. UNAIDS. Cost-effectiveness analysis and HIV/AIDS: UNAIDS Technical Update. 1998.

15. Sari IP. Penelitian Farmasi Komunitas dan Klinik, GadjahMada. Yogyakarta: University Press; 2004. P.31.

16. World Health Organization. Global Strategy on Diet, Physical Activity \& Health: Physical Activity and Adults (online). 2013.

17. Bootman JL, Townsend RJ, McGhan WF. Introduction to Pharmacoeconomics. In: Bootman JL, Townsend RJ, McGhan WF, editors. Principles of Pharmacoeconomics. 3rd. Cincinnati: Harvey Whitney Books Company; 2005. p. 1-10.

18. Skrepnek GH. Cost Effectiveness Analysis (CEA). In: Principles of Pharmacoeconomics. 3rd edition. Cincinnati: Harvey Withney Books Company; 2005. p. 83-112.

19. Bootman JL, Harrison DL. Pharmacoeconomics and Therapeutic drug monitoring. Pharm World Sci. 1997; 19: 178-81.

20. Ponziani FR, Zocco MA, Garcovich M, D'Aversa F, Roccarina D, Gasbarrini A. What we should know about portal vein thrombosis in cirrhotic patients: a changing perspective. World J Gastroenterol. 2012; 28:5014-20.

21. Congly SE, Lee SS. Portal vein thrombosis: should anticoagulation be used? Curr Gastroenterol Rep. 2013; 15: 306.

22. Kumar P, Clark M. Liver, Biliary Tract and Panreatic Disease. In: Kumar P, Clark M, editors. Kumar \& Clark's Clinical Medicine. 7th ed, London: Saunders Elsevier; 2009. p.219 \& 319-20.

23. Pagana KD, Pagana TJ. Blood Studies. In: Pagana KD, Pagana TJ, editors. Mosby's Manual of Diagnostic and Laboratory Tests. St. Louis: Mosby Elsevier; 2006. p.387-445.

24. Durand F, Valla D. Assesment of the prognosis of cirrhosis: Child-Pugh versus MELD. J Hepatol. 2005; 42: 100-7.

25. Ridwan M. Awas! Tiap Tahun 25 Ribu Orang Meninggal Akibat Sirosis Hati, PT. Lensa Indonesia Global Media (online). 2012.

26. Franciscus A. Disease Progression: What is Cirrhosis?,HCSP version 3.1.2010.

27. Bickert B, Witmer C. Coagulation Disorder. In Dipiro JT, Talbert RL, Yee GC, editors. Pharmacotherapy A Pathophysiologic Approach. 7th ed. Philadelphia: McGraw Hill Medical; 2008. p. 1665-1682.

28. Sweetman SC. Martindale the Complete Drug Reference $36^{\text {th }}$ ed. London: Pharmaceutical Press; 2009. p. 1081-996.

29. McCormick PA, Ooi H, Crosbie O.Tranexamic acid for severe bleeding gastric antral vascular ectasia in cirrhosis. Gut. 1998; 42: 750-2. 